\title{
Production of xylanase by Aspergillus sp. ART500.1 on agroindustrial residues and its biochemical properties
}

Produção de xilanase por Aspergillus sp. ART 500.1 em resíduos agroindustriais e propriedades bioquímicas

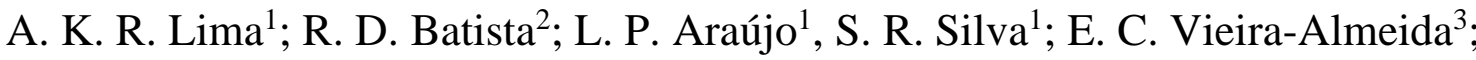 \\ A. F. Almeida ${ }^{2 *}$ \\ ${ }^{1}$ Laboratório de Biotecnologia, Análise de Alimentos e Produtos, Universidade Federal do Tocantins (UFT), \\ 77404-970, Gurupi-TO, Brasil \\ ${ }^{2}$ Programa de Pós-Graduação em Ciência e Tecnologia de Alimentos, Universidade Federal do Tocantins, \\ 77001-090, Palmas-TO, Brasil \\ ${ }^{3}$ Graduação em Farmácia, Universidade de Gurupi, 77403-090, Gurupi-TO, Brasil \\ *alexfernando@uft.edu.br \\ (Trabalho avaliado e selecionado pela Comissão do III CTOCTA)
}

\begin{abstract}
The aim of this work was to evaluate the use of different agro-industrial residues for the production of xylanase by Aspergillus sp. ART 100.1, as well as analyzing the biochemical properties of the enzyme. Agroindustrial residues malt bagasse, pineapple crown, açaí bagasse and soybean husk present in large quantities in the Tocantins region were used to evaluate the production of xylanase. Cultivation conditions for xylanase production were evaluated in submerged and solid-state cultivation. The highest production of xylanase in submerged cultivation was obtained using soybean husk residue $(23.60 \mathrm{U} / \mathrm{mL})$, while, for solidstate cultivation conditions, the highest production of xylanase was obtained with malt bagasse $(110.00$ $\mathrm{U} / \mathrm{g}$ ). The effect of additives to the culture medium was also evaluated, with the best result for the use of the xylose additive in the pineapple crown in solid-state cultivation. The enzyme produced in solid-state cultivation was characterized in terms of $\mathrm{pH}$ and temperature. The optimum activity $\mathrm{pH}$ was observed at 5.0 and for temperature at $55^{\circ} \mathrm{C}$. The xylanase was stable in a $\mathrm{pH}$ range between 4 and 5 and retained $50 \%$ of its activity at $45{ }^{\circ} \mathrm{C}$ after 110 minutes. The Aspergillus sp. ART 500.1 presents potential for the production of xylanase using agro-industrial residues, enabling the development of bioprocesses for the scaling of production.
\end{abstract}

Keywords: xylanase, agro-industrial residue, biochemical characterization.

O objetivo deste trabalho foi avaliar o uso de diferentes resíduos agroindustriais para a produção de xilanase por Aspergillus sp. ART 100.1, bem como analisar as propriedades bioquímicas da enzima. Os resíduos agroindustriais bagaço de malte, coroa de abacaxi, bagaço de açaí e casca de soja presentes em grande quantidade na região do Tocantins foram utilizados para avaliar a produção de xilanase. As condições de cultivo para a produção de xilanase foram avaliadas em cultivos submersos e em estado sólido. A maior produção de xilanase nos cultivos submersos foi obtida utilizando o resíduo casca de soja $(23,60 \mathrm{U} / \mathrm{mL})$, enquanto, para as condições de cultivo em estado sólido, a maior produção de xilanase foi obtida com bagaço de malte $(110,00 \mathrm{U} / \mathrm{g})$. O efeito de aditivos ao meio de cultivo também foi avaliado, tendo o melhor resultado para o uso do aditivo xilose na coroa de abacaxi em cultivo em estado sólido. A enzima produzida em estado sólido foi caracterizada quanto ao $\mathrm{pH}$ e temperatura. $\mathrm{O} \mathrm{pH}$ ótimo de atividade foi observado em 5,0 e para temperatura em $55^{\circ} \mathrm{C}$. A xilanase se mostrou estável numa faixa de $\mathrm{pH}$ entre 4 e 5 e reteve $50 \%$ da sua atividade a $45^{\circ} \mathrm{C}$ após 110 minutos. A linhagem Aspergillus sp. ART 500.1 apresenta potencial para a produção de xilanase utilizando resíduos agroindustriais viabilizando o desenvolvimento de bioprocessos para o escalonamento da produção.

Palavras-chave: xilanase, resíduo agroindustrual, caracterização bioquímica.

\section{INTRODUCTION}

Some microorganisms produce enzymatic complexes that degrade hemicellulose, cellulose and lignin present in plant cell walls, releasing sugars with potential for applications in fermentation processes, generating products with high economic value [1]. Filamentous fungi are the main source of cellulases and hemicellulases [2]. Fungi have high extracellular release and 
enzymatic yield, ensuring greater activity compared to bacteria or yeasts, being major producers of xylanase [3].

Enzymes are components of the metabolism of microorganisms responsible for catalyzing chemical reactions essential for cell maintenance, being useful in many applications such as biology, engineering, biotechnology and industry [4]. Xylanases are enzymes responsible for the hydrolysis of $\beta-1,4$ glycosidic bonds present in xylan. Xylan is a xylose polymer that is associated with other sugars forming glucuronoxylans, glucuronoarabinoxylans and glucomannans [5]. Xylanases can hydrolyze bonds inside and at the ends of the polymer, being called endoxylanases and exoxylanases [6].

The production of enzymes is a market in evidence thanks to an increasingly significant increase in their use in various industrial processes. However, the high production cost associated with the steps of purification, formulation and high price of the substrate, still limits the consolidation of this market [7]. Thus, alternatives for enzyme production and cost reduction are intensively studied to replace some synthetic substrates with low value products such as agroindustrial residues, adding value and reducing the environmental impact of this residue on the environment [8]. In this context, the objective of this work was to analyze agro-industrial residues as a carbon source, in solid and submerged crops, using a strain of Aspergillus sp. ART 500.1 isolated from the fruit of Araticum (Annona crassiflora) and using an additive (xylose) in order to improve its cultivation conditions and characterize the biochemical properties of the enzyme produced.

\section{MATERIALS AND METHODS}

The experiments were conducted at the Laboratory of Biotechnology, Analysis of Food and Products (LABAP) of Habite - Incubator of Biotechnology Companies at the Federal University of Tocantins, Campus de Gurupi, located in the southwest region of the state of Tocantins.

\subsection{Microorganism and inoculum}

Aspergillus sp. ART 500.1 was isolated from Araticum fruits in spontaneous fermentation. The stock culture was maintained and stored using the Castellani method at $4{ }^{\circ} \mathrm{C}$. Peaks were periodically performed in slant tubes containing potato dextrose agar medium and incubated at $28{ }^{\circ} \mathrm{C}$. After 5 days of cultivation, the Aspergillus sp. ART 500.1 was kept in slanted tubes and the spores were suspended in $0.85 \%$ saline solution at a concentration of $10^{7}$ spores $/ \mathrm{mL}$. The cultures were added with $1 \mathrm{~mL}$ of this suspension in liquid and solid culture media.

\subsection{Agro-industrial residues}

Four agro-industrial residues were selected to be used as a carbon source: pineapple crown, malt bagasse, açaí bagasse and soybean husk. The residues were in an oven at $70{ }^{\circ} \mathrm{C}$ for 48 hours, then crushed in a knife mill (particle size $=1 \mathrm{~mm}$ ).

\subsection{Culture media preparation}

For the submerged culture medium, the experiments were carried out in Erlenmeyer flasks $(125 \mathrm{~mL})$ containing $20 \mathrm{~mL}$ of Mandel and Weber medium [9]: $\mathrm{KH}_{2} \mathrm{PO}_{4} 2.0 \mathrm{~g} / \mathrm{L}$; $\left(\mathrm{NH}_{4}\right)_{2} \mathrm{SO}_{4} 1.4$ $\mathrm{g} / \mathrm{L}$; urea $0.3 \mathrm{~g} / \mathrm{L} ; \mathrm{CaCl}_{2} .2 \mathrm{H}_{2} \mathrm{O} 0.3 \mathrm{~g} / \mathrm{L} ; \mathrm{MgSO}_{4} .7 \mathrm{H}_{2} \mathrm{O} 0.3 \mathrm{~g} / \mathrm{L} ; \mathrm{FeSO}_{4} .7 \mathrm{H}_{2} \mathrm{O} 5.0 \mathrm{mg} / \mathrm{L} ; \mathrm{MnSO}_{4} . \mathrm{H}_{2} \mathrm{O}$ $1.6 \mathrm{mg} / \mathrm{L} ; \mathrm{ZnSO}_{4} .7 \mathrm{H}_{2} \mathrm{O} 1.4 \mathrm{mg} / \mathrm{L} ; \mathrm{CoCl}_{2} 2.0 \mathrm{mg} / \mathrm{L}$; yeast extract $1.0 \mathrm{~g} / \mathrm{L}$ and peptone $1.0 \mathrm{~g} / \mathrm{L}$. Submerged cultures were supplemented with $0.2 \mathrm{~g}$ of each carbon source. The $\mathrm{pH}$ was adjusted to 6.0 and after inoculation, the culture remained incubated at $28{ }^{\circ} \mathrm{C}, 180 \mathrm{rpm}$ for 72 hours. For the solid-state cultivation, $10 \mathrm{~g}$ of each carbon source were weighed and $10 \mathrm{~mL}$ of Mandel and Weber medium [9] were added, $\mathrm{pH}$ adjusted to 6 in autoclavable bags $(12 \times 14 \mathrm{~cm})$. The bags were 
sealed with staples at the ends, after inoculation the culture remained in the greenhouse at $28{ }^{\circ} \mathrm{C}$ for 120 hours.

\subsection{Effect of glucose and xylose on xylanase production}

The effect of xylose or glucose addition on xylanase production was analyzed by adding $1 \%$ $(\mathrm{w} / \mathrm{w})$. The cultivations were carried out in autoclavable bags containing $10 \mathrm{~g}$ of pineapple crown, soybean husk or barley spent grain and moistened with Mandel and Weber medium [9] with $\mathrm{pH}$ adjusted to 6.0. Cultivations were kept at $28^{\circ} \mathrm{C}$. Controls were carried out without the addition of additives. The cultures were maintained for 168 hours with samples taken every 24 hours and carried out in triplicate.

\subsection{Crude extract}

The clarification of the enzymatic extract was carried out by filtration process using Mucelini cloths cut to a diameter of $12.5 \mathrm{~cm}$, placed in a Büchner funnel coupled to the kitassate and vacuum pump. The filtrate was centrifuged for 10 minutes at $10,000 \mathrm{~g}$ at $4{ }^{\circ} \mathrm{C}$. The supernatant was collected and used for enzyme activity analysis.

\subsection{Xylanolytic activity assay}

Xylanase activity was performed using a 1\% (w/v) xylan solution in McIlvaine $\mathrm{pH} 5.0$ buffer. Four hundred milliliters of this solution were added to test tubes and kept for 5 minutes in a water bath at $50{ }^{\circ} \mathrm{C}$. To start the reaction, $0.4 \mathrm{~mL}$ of the enzymatic extract was added, $0.2 \mathrm{~mL}$ being removed at time 0 (control), 5 and $10 \mathrm{~min}$, adding to tubes containing $0.2 \mathrm{~mL}$ of DNS at the end of each time. Tubes with DNS were boiled in boiling water for $5 \mathrm{~min}$. It was allowed to cool, and $2.0 \mathrm{~mL}$ of ultrapure water was added and analyzed in a spectrophotometer at $540 \mathrm{~nm}$. The presence of reducing sugars was evaluated according to Miller [10]. One unit of enzyme was determined as the amount of enzyme needed to release $1 \mu \mathrm{mol}$ of xylose per milliliter per minute.

\subsection{Biochemical properties}

\subsubsection{Effect of $\mathrm{pH}$ and temperature on xylanolytic activity}

The effect of $\mathrm{pH}$ on the enzymatic activity was performed in different reaction media containing $1 \%$ xylan $(\mathrm{w} / \mathrm{v})$ with $\mathrm{pH}$ values ranging from 3.0 to 8.0 with 0.5 intervals.

The effect of temperature on enzymatic activity was analyzed at different temperatures from 25 to $75^{\circ} \mathrm{C}$.

\subsubsection{Thermal and $p H$ stability}

The stability of the enzyme at different $\mathrm{pH}$ was performed in McIlvaine buffers with a $\mathrm{pH}$ of 3 to 8 , with an interval of 0.5 . Enzyme was diluted 1:2(v/v) for each buffer. The experiment was kept at $25^{\circ} \mathrm{C}$ for 24 hours and enzyme activity was analyzed in the initial and final time.

The thermal stability of the enzyme was performed at different temperatures without the presence of substrate. The enzyme was diluted in buffer and incubated in a water bath at temperatures $45,50,55$ and $60{ }^{\circ} \mathrm{C}$. Samples were collected at a time interval of $0,5,10,15,20$, $30,40,60,90$ and 120 minutes and placed in an ice bath. The xylanolytic activity was performed using the extract collected at each different time interval, using optimum activity temperature and $\mathrm{pH}$. 


\section{RESULTS AND DISCUSSION}

\subsection{Xylanase production in submerged and solid-state cultivations}

Figure 1 shows the results for extracellular xylanase production by Aspergillus sp. ART 500.1 in submerged and solid-state cultivations, using agro-industrial residues. In submerged cultivation, the highest level of xylanase production was observed with soybean husks (23.60 $\mathrm{U} / \mathrm{mL})$, followed by açaí bagasse $(16.00 \mathrm{U} / \mathrm{mL})$ with orbital agitation. Pineapple crown and barley spent grain produced $5.60 \mathrm{U} / \mathrm{mL}$ of xylanase, respectively (Figure 1A).

$\mathbf{A}$

Submerged cultivation

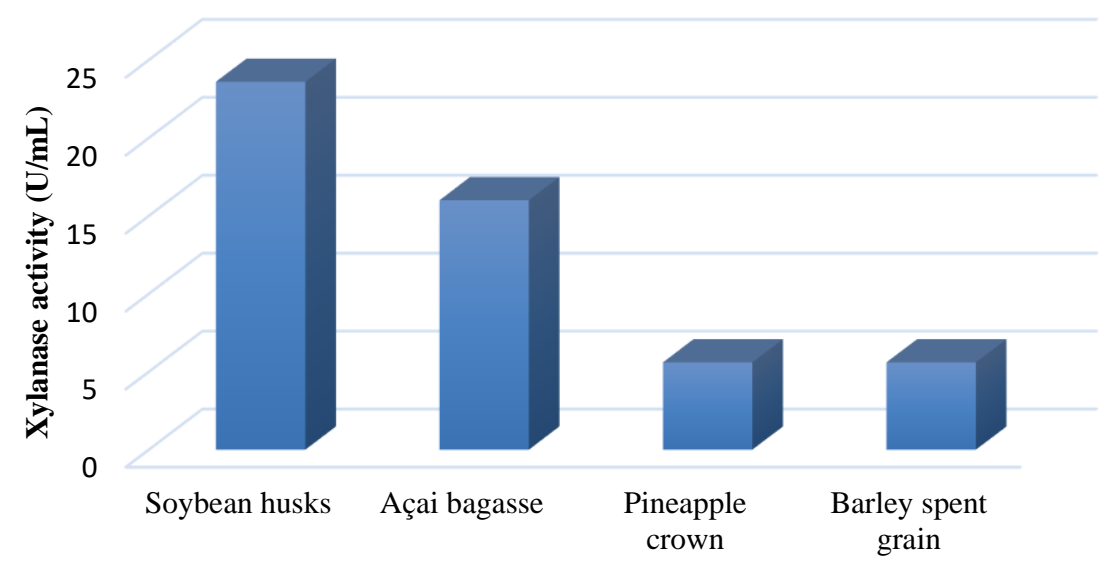

Agro-industrial residues

B Solid-state cultivation

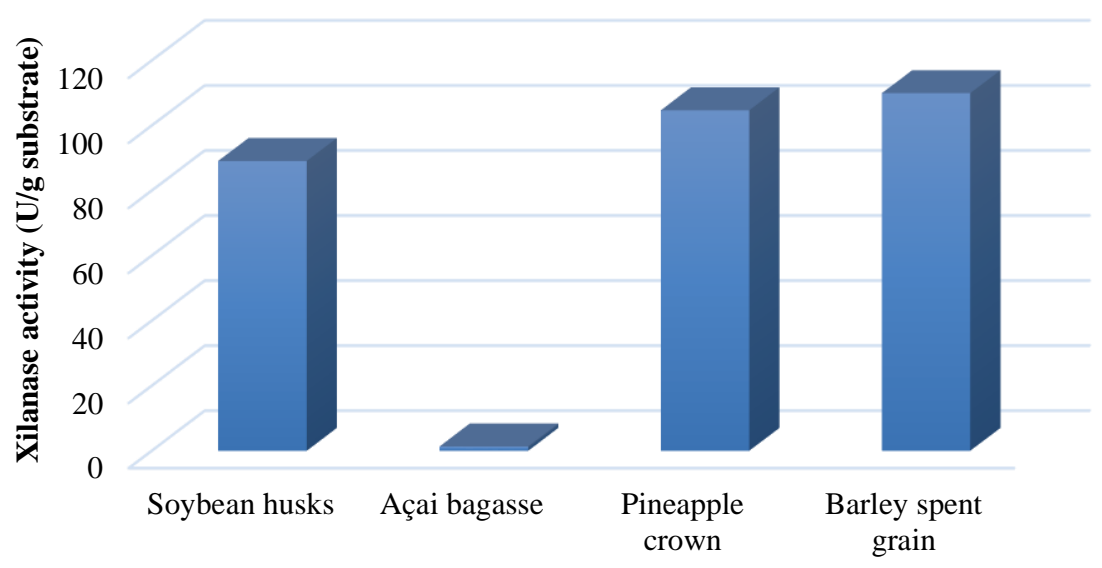

Agro-industrial residues

Figure 1. Xylanase production by Aspergillus sp. ART 500.1 in submerged cultivation (A) and solid-state cultivation (B). Experimental conditions: submerged cultivation performed for 72 hours, at $28^{\circ} \mathrm{C}, 180$ rpm; solid-state cultivation carried out at $28^{\circ} \mathrm{C}, 50 \%$ humidity for 72 hours.

The use of agro-industrial residues for the production of enzymes has been concentrated in the production of xylanase using corn cob, citrus pectin, beet pulp, wheat straw and wheat bran have shown to have the potential capacity to induce the xylanolytic and hemicellulolytic complexes for the enzyme production [11]. Submerged crops represent the vast majority of bioprocesses for enzyme production. The optimization of xylanase production by Aspergillus foetidus was 
achieved using soybean hulls after seven days of submerged cultivation $(9.72 \mathrm{U} / \mathrm{mL})$ [12]. Javed et al. (2019) [13] studied the production of xylanase by Aspergillus niger KIBGE-IB36 using residues of corn cob, wheat bran, rice husk, orange peel, pomegranate peel and potato starch in submerged crops. The xylanase activity was considered maximum (3071 U/mg) when $1 \%$ wheat bran was used as substrate. Xylanase production was not observed in the presence of potato starch.

Solid-state cultivation, in many studies, show better yields in enzyme production when compared to submerged cultivation. In this study, solid-state cultivation showed higher levels of productivity for xylanase production by Aspergillus sp. ART500.1. The highest activities were observed with barley spent grain $(110.00 \mathrm{U} / \mathrm{g})$, pineapple crown $(104.70 \mathrm{U} / \mathrm{g})$, soybean husks $(89.10 \mathrm{U} / \mathrm{g})$. Açaí bagasse had the lowest xylanase production $(1.30 \mathrm{U} / \mathrm{g})$ (Figure 1B). Singh et al. (2021) [14] evaluated the production of xylanase by Aspergillus flavus in solid-state cultivation with different agro-industrial substrates. In this work, the highest production of xylanase was observed with pretreated rice husks. Kronbauer et al. (2007) [15] observed that the production of xylanase with barley spent grain in solid-state cultures by Aspergillus casiellus was $92.20 \mathrm{U} / \mathrm{g}$ after 96 hours.

Enzyme induction in submerged cultivation is highly influenced by different parameters such as carbon sources, temperature, $\mathrm{pH}$ and operational parameters such as incubation times, agitation. In this work, the results indicate that the carbon source and the cultivation system are the main factors influencing the production of xylanase. Considering the highest yields of xylanase in solid-state cultivations, the other experiments were carried out using soybean husk, pineapple crown and malt bagasse.

\subsection{Effect of glucose and xylose}

Aspergillus sp. ART 500.1 cultivations were carried out in solid-state with the addition of glucose or xylose for 168 hours (Figure 2). The addition of glucose in the culture media of soybean husk and barley spent grain reached the maximum xylanase production of $32.50 \mathrm{U} / \mathrm{g}$ substrate and $31.20 \mathrm{U} / \mathrm{g}$ substrate, respectively. In pineapple crown cultivation, the addition of glucose induced the production of $225.00 \mathrm{U} / \mathrm{g}$ substrate after 168 hours of cultivation. The addition of xylose to the culture media had distinct effects on enzyme production. In pineapple crown cultivation, the addition of xylose promoted the production of $272.30 \mathrm{U} / \mathrm{g}$ substrate after 144 hours of cultivation, causing repression in xylanase production. The addition of xylose in pineapple crown induced the production of $271.20 \mathrm{U} / \mathrm{g}$ xylanase substrate after 144 hours, while the control cultures produced $236.80 \mathrm{U} / \mathrm{g}$ substrate after 120 hours. The results for soybean husk show that the addition of xylose had no effect on the production of xylanase, with the highest values observed being $99.50 \mathrm{U} / \mathrm{g}$ substrate for control and $95.60 \mathrm{U} / \mathrm{g}$ substrate for cultivations with addition of xylose. However, in cultures with barley spent grain, xylose had a similar repressive effect on xylanase production to cultures with the addition of glucose with the maximum observed enzyme production of $28.90 \mathrm{U} / \mathrm{g}$ substrate after 144 hours of cultivation. In this substrate, the highest production of xylanase was observed in the control cultures after 120 hours (108.00 U/g substrate).

Faria et al. (2019) [16] evaluated the production of xylanase by strains of Moesziomyces spp. using xylose, xylan and barley bagasse. In this work, the evaluated strains were able to grow and produce xylanolytic enzymes using all substrates tested, showing robust and versatile enzyme production systems when induced by barley bagasse, xylose or xylan. The presence of glucose in the pretreated barley bagasse did not harm enzyme production, probably because this sugar was first consumed during the initial growth phase. The xylanase production by Colletotrichum graminicola on solid substrates showed that the supplementation of wheat bran with $1 \%$ ground corncob slightly increased the xylanase production. Most of the other supplemental carbon sources tested, including xylan, had no effect, while xylose inhibited about 33\% of enzyme production [17]. 
A

Soybean husks

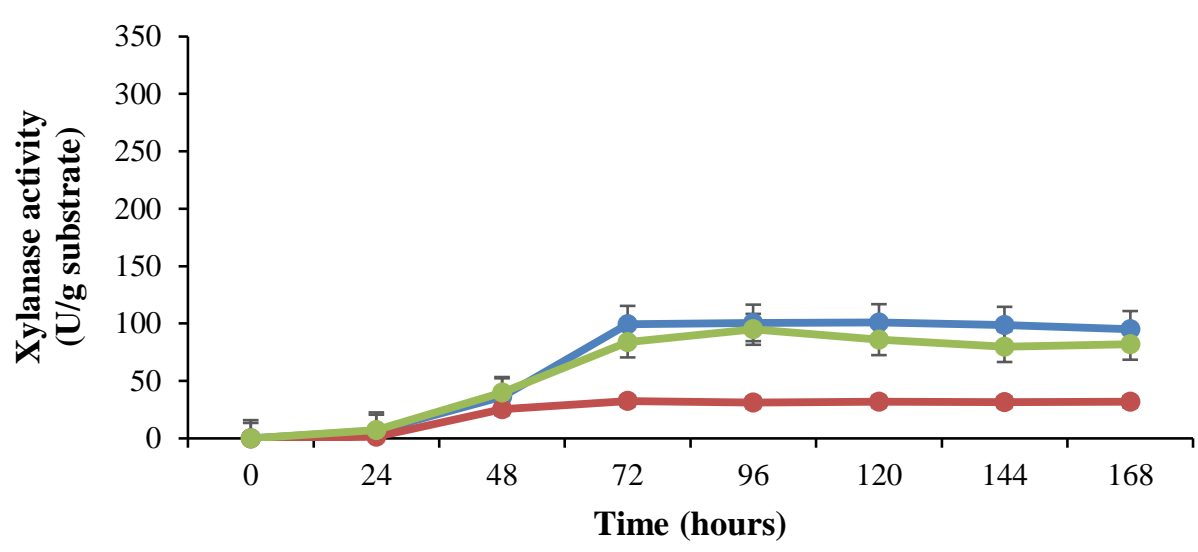

$\longrightarrow$ Control $\longrightarrow$ Glucose $\longrightarrow$ Xylose

B Pineapple crown

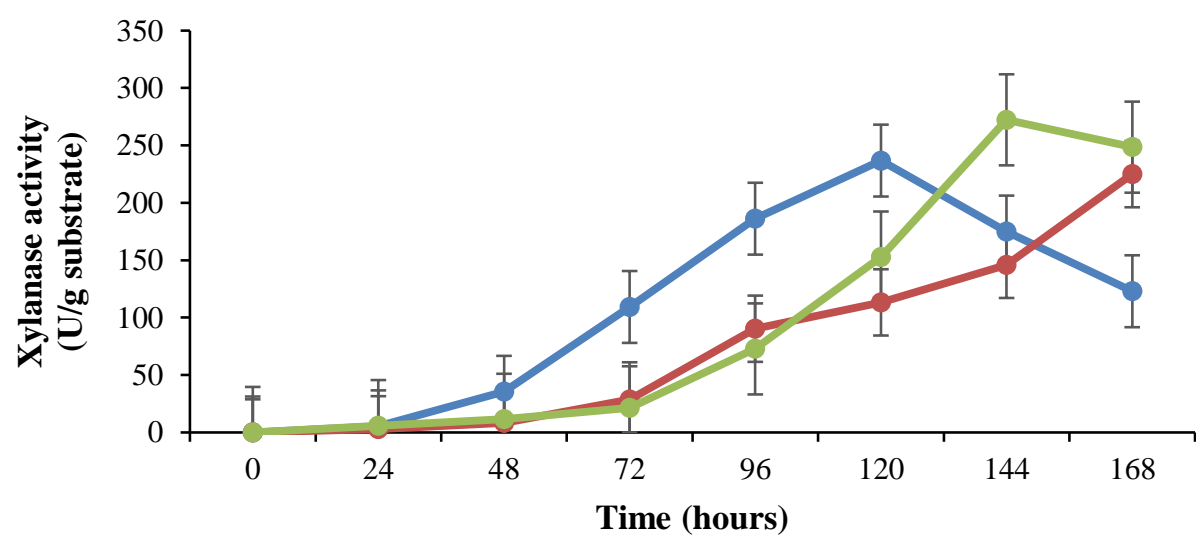

$\longrightarrow$ Control $\longrightarrow$ Glucose $\longrightarrow$ Xylose

C Barley spent grain

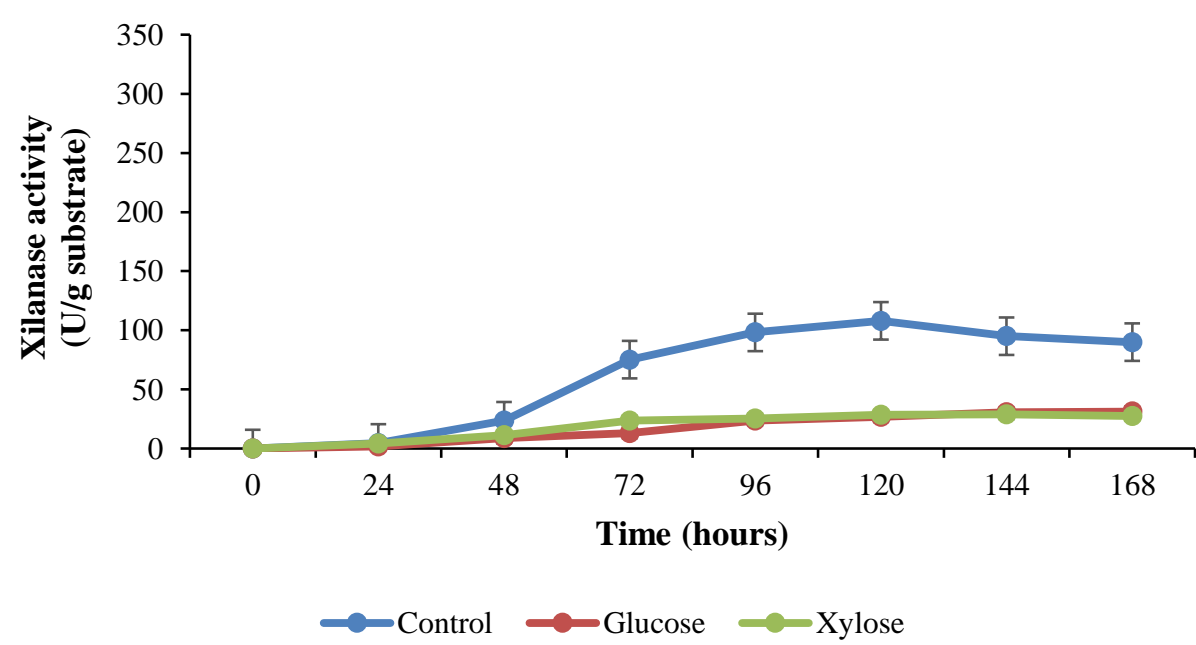

Figure 2. Effect of addition of glucose and xylose on xylanase production by Aspergillus sp. ART 500.1 in solid state crops using $(A)$ soybean husk, $(B)$ pineapple crown and $(C)$ malt bagasse. Growing conditions: solid-state cultivation was maintained at $28^{\circ} \mathrm{C}, 50 \%$ humidity. 


\subsection{Biochemical properties of xylanase}

\subsubsection{Effect of pH and tempertature on enzyme activity}

The biochemical properties of an enzyme, such as $\mathrm{pH}$ and optimum activity temperature, are important operational information for the application of enzymes in industrial processes. The xylanase produced by Aspergillus sp. ART 500.1 in solid state cultivation showed optimal activity at $\mathrm{pH} 5.0(100 \%)$. Above $\mathrm{pH} 5.0$, a decrease in activity was observed up to $\mathrm{pH} 8.0(7.63 \%)$ (Figure $3)$. The xylanase produced by Penicillium roqueforti ATCC 10110 showed maximum activity at $\mathrm{pH} 3.0$, but with similar values at $\mathrm{pH} 4.0$ and $\mathrm{pH} 5.0$ [18]. According to the authors, the favorable behavior of enzymes in acidic $\mathrm{pH}$ ranges may be the result of a positive unfolding on the protein's amino acid residues, resulting in increased exposure of the enzyme's active site and the occurrence of the reaction [18]. Krisana et al. (2005) [19] observed optimal pH 5.0 for the A. niger BCC14405 strain.

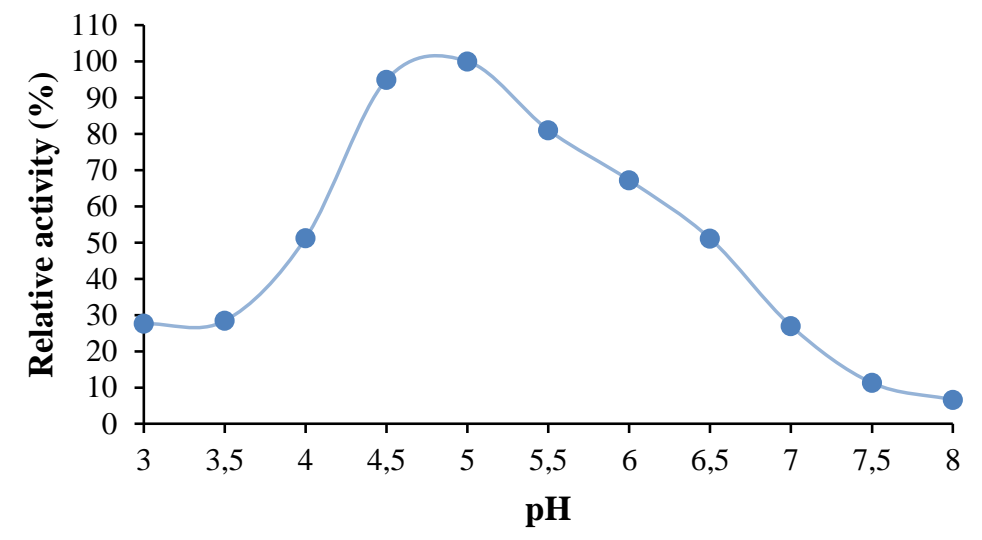

Figure 3. Optimal pH of xylanase produced by Aspergillus sp. ART 500.1 on solid-state cultivation.

The optimum temperature of the enzyme produced by Aspergillus sp. ART 500.1 is shown in Figure 4. Xylanase showed optimal activity between temperatures of $55^{\circ} \mathrm{C}$ and $60{ }^{\circ} \mathrm{C}(100 \%)$. Above this temperature there was a strong reduction in enzymatic activity promoted by the denaturation of the enzyme. Temperatures below $55{ }^{\circ} \mathrm{C}$ showed a milder reduction, reaching $50 \%$ of the enzymatic activity at $25^{\circ} \mathrm{C}$. Similar results were observed by Souza et al. (2018) [18]. The xylanase activity produced by $P$. roqueforti ATCC 10110 gradually increased with increasing reaction temperature, reaching a maximum value of $60{ }^{\circ} \mathrm{C}$. Subsequently, there was a decrease in enzymatic activity, however, not exceeding $40 \%$ even at maximum temperature.

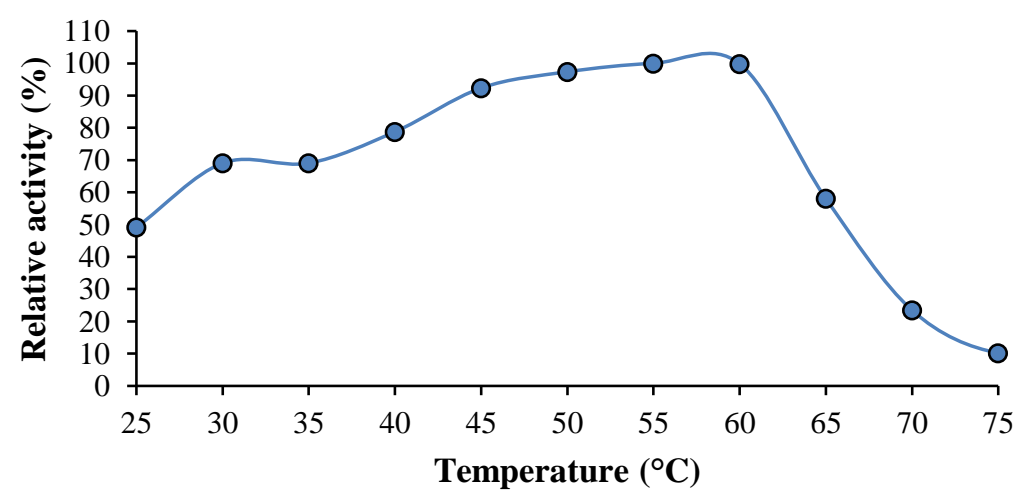

Figure 4. Optimal temperature of xylanase produced by Aspergillus sp. ART 500.1 on solid-state cultivation. 


\subsubsection{Thermal stability and $p H$}

Xylanase from Aspergillus sp. ART 500.1 showed greater stability between $\mathrm{pH} 3.0$ and 4.5 $(\sim 100 \%)$ (Figure 5). Above these $\mathrm{pH}$ values the activity gradually reduced until reaching $25 \%$ at $\mathrm{pH}$ 8. The pH stability study is essential for the characterization of an enzyme before it can be commercially exploited. Xylanase from Pencilium glabrum was stable between $\mathrm{pH}$ 2.5-5.0 (80\%) [20]. Results similar to those obtained in this work were found by Souza et al. (2018) [18]. The xylanase produced by $P$. roqueforti ATCC 10110 showed stability above $70 \%$ between $\mathrm{pH} 3.0$ and 5.0 after $5.0 \mathrm{~h}$ at $50{ }^{\circ} \mathrm{C}$ and at $\mathrm{pH} 6.0$ there was a decrease of $46 \%$. After $3.0 \mathrm{~h}$ at $\mathrm{pH} 7.0$ and 8.0 , significant reductions in activity until enzyme inactivation were observed.

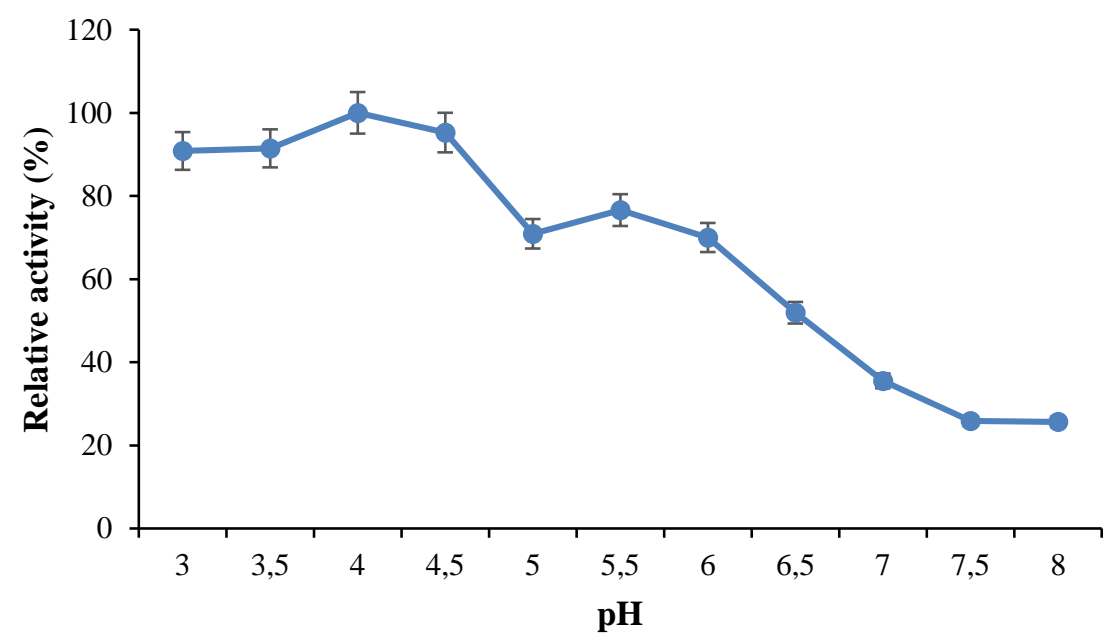

Figure 5. pH stability of xylanase produced by Aspergillus sp. ART 500.1 on solid-state cultivation.

Regarding the enzymatic thermostability shown in Figure 6, the enzyme was more stable at a temperature of $45{ }^{\circ} \mathrm{C}$, maintaining the relative activity at $90 \%$ for $30 \mathrm{~min}$. After this period, the relative activity dropped to $76 \%$ in $90 \mathrm{~min}$, in $105 \mathrm{~min}$ the relative activity dropped to $50 \%$, showing that the xylanase remains stable up to the time of approximately $90 \mathrm{~min}$ at a temperature of $45^{\circ} \mathrm{C}$. For the temperature at $55^{\circ} \mathrm{C}$, in $5 \mathrm{~min}$ it showed a relative activity of $40 \%$, remaining so for up to $20 \mathrm{~min}$. For temperatures of $60{ }^{\circ} \mathrm{C}$ and $65^{\circ} \mathrm{C}$ the relative activities were $30 \%$ with 5 minutes, being inappropriate temperatures for applications as they do not guarantee the stability of the enzyme. Similar results were obtained for xylanase from A. foetidus where the enzyme showed high stability at intermediate temperatures and no activity was observed at $75^{\circ} \mathrm{C}$ [12].

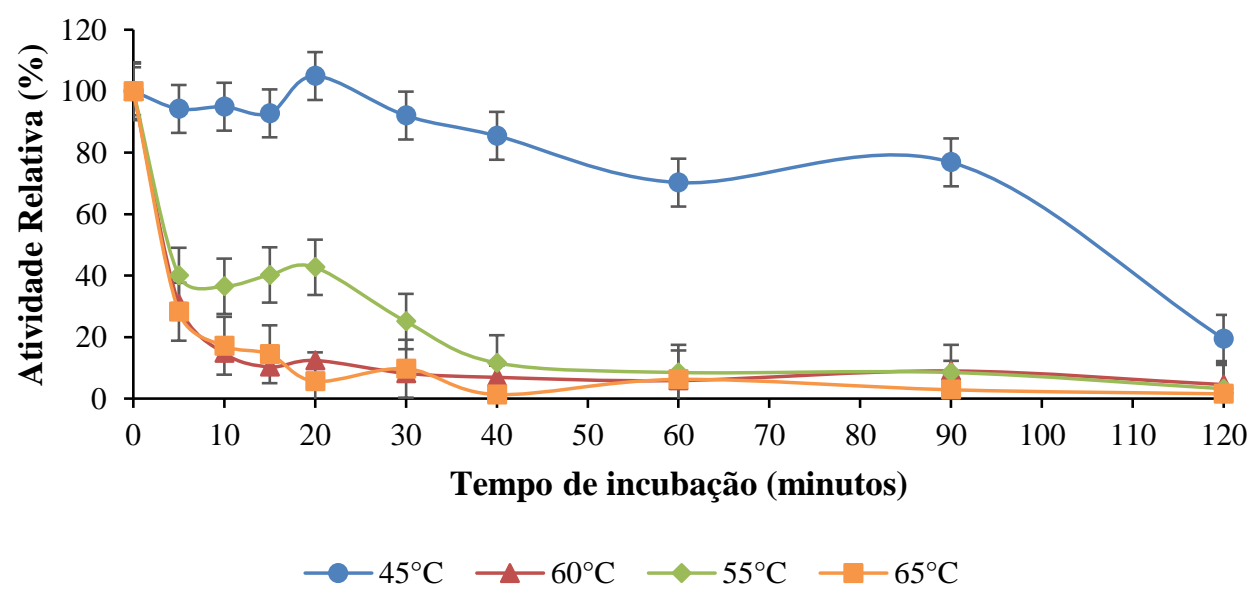

Figure 6. Thermostability of xylanase produced by Aspergillus sp. ART 500.1 on solid-state cultivation. 


\section{CONCLUSION}

The production of xylanase by Aspergillus sp. ART 500.1 evaluated on different agroindustrial substrates was more efficient with solid-state soybean husks in submerged crops. Agroindustrial residues supplementation showed that pineapple crown supplemented with xylose increased xylanase production after 144 hours of cultivation, while glucose had a repressive effect on enzyme production. The enzyme produced in solid-state cultivation had an optimal $\mathrm{pH}$ between 5.0-5.5 and an optimal activity between 55 and $60{ }^{\circ} \mathrm{C}$. The enzyme showed stability at a temperature of $45{ }^{\circ} \mathrm{C}$ and a $\mathrm{pH}$ stability range from 3.0 to 4.5 . The production of xylanase by Aspergillus sp. ART 500.1 in different agro-industrial residues presents potential for the exploration of new alternatives for the production of enzymes and their scaling for production in pilot scales.

\section{REFERENCES}

1. Brink JVD, Vries RP. Fungal enzyme sets for plant polysaccharide degradation. Appl Microbiol Biotechnol. 2011 Jul;91(6):1477-92. doi: 10.1007/s00253-011-3473-2

2. Gusakov AV, Salanovich TN, Antonov AI, Ustinov BB, Okunev ON, Burlingame R, et al. Design of highly efficient cellulase mixtures for enzymatic hydrolysis of cellulose. Biotechnol Bioeng. 2007 Aug;97(5):1028-38. doi: 10.1002/bit.21329

3. Burlacu A, Cornea CP, Israel-Roming, F. Microbial xylanase: a review. Sci Bull Series F. Biotechnol. 2016;20:335-42.

4. Alokika, Singh B. Production, characteristics, and biotechnological applications of microbial xylanases. Appl Microbiol Biotechnol. 2019 Oct;103(21-22):8763-84. doi: 10.1007/s00253-019-10108-6

5. Singh S, Sidhu GK, Kumar V, Dhanjal DS, Datta S, Singh J. Fungal xylanases: sources, types, and biotechnological applications. In: Yadav A, Mishra S, Singh S, Gupta A, editors. Recent advancement in white biotechnology through fungi. Vol. 1, Diversity and enzymes perspectives. Cham $(\mathrm{CH})$ : Springer, Cham; 2019. doi: 10.1007/978-3-030-10480-1_12

6. Linares-Pastén JA; Aronsson A, Karlsson EN. Structural considerations on the use of endo-xylanases for the production of prebiotic xylooligosaccharides from biomass. Curr Protein Pept Sci. 2018 Jan;19(1):48-67. doi: 10.2174/1389203717666160923155209

7. Bomtempo FVS, Carreiro SC, Pimenta RS, Guarda EA. Produção de extratos enzimáticos por fungos filamentosos utilizando resíduos agrícolas. Bioenergia em Revista: Diálogos. 2017 Jan;7(1):26-44.

8. Maidana SA, Esteche VP, Hours RA, Brumovsky LA, Martos MA. Use of agro-industrial wastes for the production of a wild yeast enzyme with disintegration activity on plant tissues. Braz Arch Biol Techn. 2020 Mar;63:e20190515. doi: 10.1590/1678-4324-2020190515

9. Mandels M, Weber J. The production of cellulases. In: Hajny GJ, Reese ET, editors. Cellulases and their applications. Washington DC (US): American Chemical Societ; 1969. p. 391-414. doi: 10.1021/ba1969-0095.ch023

10. Miller GL. Use of dinitrosalicylic acid reagent for determination of reducing sugar. Anal Chem. 1959 Mar;31(3):426-8. doi: 10.1021/ac60147a030

11. Kumar V, Chhabra D, Shukla P. Xylanase production from Thermomyces lanuginosus VAPS-24 using low cost agro-industrial residues via hybrid optimization tools and its potential use for saccharification. Bioresour Technol. 2017 Nov;243(2017):1009-19. doi: 10.1016/j.biortech.2017.07.094

12. Cunha L, Matarello R, Souza PM, Freitas MM, Barros KVG, Ferreira Filho EX, et al. Optimization of xylanase production from Aspergillus foetidus in soybean residue. Enz Res. 2018 Feb;2018:6597017. doi: $10.1155 / 2018 / 6597017$

13. Javed U, Ansari A, Aman A, Qader SAU. Fermentation and saccharification of agro-industrial wastes: A cost-effective approach for dual use of plant biomass wastes for xylose production. Biocatal Agric Biotechnol. 2019 Sep;21:101341. doi: 10.1016/j.bcab.2019.101341

14. Singh A, Bajar S, Devi A, Bishoni NR. Adding value to agro-industrial waste for cellulase and xylanase production via solid-state bioconversion. Biomass Conv Bioref. 2021 Apr. doi: 10.1007/s13399-02101503-z

15. Kronbauer EAW, Peralta RM, Osaku CA, Kadowaki MK. Produção de xilanase por Aspergillus Casielus com diferentes fontes de carbono. Bol Centro Pesqui Process Alim. 2007 Dec;25(2):207-16. doi: $10.5380 /$ cep.v25i2.10608

16. Faria NT, Marques S, Ferreira FC, Fonseca C. Production of xylanolytic enzymes by Moesziomyces spp. using xylose, xylan and brewery's spent grain as substrates. New Biotechnol. 2019 Mar;49:13743. doi: 10.1016/j.nbt.2018.11.001 
17. Zimbardi ALRL, Sehn C, Meleiro LP, Souza FHM, Masui DC, Nozawa MSF, et al. Optimization of $\beta$ glucosidase, $\beta$-xylosidase and xylanase production by Colletotrichum graminicola under solid-state fermentation and application in raw sugarcane trash saccharification. Int J Mol Sci. 2013 Jan;14(2):2875-902. doi: 10.3390/ijms14022875

18. Souza LO, Brito AR, Bonomo RCF, Santana NB, Ferraz JLAA, Aguiar-Oliveira E, et al. Comparison of the biochemical properties between the xylanases of Thermomyces lanuginosus (Sigma ${ }^{\circledR}$ ) and excreted by Penicillium roqueforti ATCC 10110 during the solid-state fermentation of sugarcane bagasse. Biocatal Agric Biotechnol. 2018 Oct;16:277-84. doi: 10.1016/j.bcab.2018.08.016

19. Krisana A, Rutchadaporng S, Jarupan G, Lily E, Sutipa, T, Kanyawim K. Endo-1,4-beta-xylanase B from Aspergillus cf. niger BCC14405 isolated in Thailand: purification, characterization and gene isolation. J Biochem Mol Biol. 2005 Jan;38(1):17-23. doi: 10.5483/bmbrep.2005.38.1.017

20. Knob A, Beitel SM, Fortkamp D, Terrasan CRF, Almeida AF. Production, purification, and characterization of a major Penicillium glabrum xylanase using brewer's spent grain as substrate. BioMed Res Int. 2013 Apr;2013:728735. doi: 10.1155/2013/728735 